\title{
Interferon Alfa-N3
}

National Cancer Institute

\section{Source}

National Cancer Institute. Interferon Alfa-N3. NCI Thesaurus. Code C30136.

A formulated therapeutic analog of the endogenous alpha interferon containing multiple interferon species with antiviral and antitumor properties. Interferons bind to specific cellsurface receptors, leading to the transcription and translation of genes with an interferon-specific response element, thereby inducing: antiviral effects (the most important being inhibition of viral protein synthesis); antiproliferative effects (including inhibition of cellular growth and alteration of cellular differentiation); anticancer effects (including interference with oncogene expression); and immune-modulating effects (including activation of natural killer cells, alteration of cell surface antigen expression, and augmentation of lymphocyte and macrophage cytotoxicity). (NCI04) 